\title{
Polska literatura dziecięca i młodzieżowa w odbiciu crip theory Wybrane przykłady
}

Polish children's and youth literature in the reflection of crip theory Chosen examples

Abstract: Author presents the crip theory and its possibility for interpretation of Polish children's and youth literature. She is focused on the presentation this theory and its compatibility to Polish culture. In the next part of the paper, author analyses poem To my students (Do moich uczniów) by Jan Twardowski and the novel Pupa (Poczwarka) by Dorota Terakowska, using the crip category.

Keywords: crip theory, disability, Dorota Terakowska, Jan Twardowski

\section{Kalecy/dziwacy: od lekceważenia do emancypacji}

W każdym języku europejskim ${ }^{1}$ można znaleźć określenia stygmatyzujące daną grupę społeczną lub mające lekceważący wydźwięk. Niekiedy w miarę upływu czasu oraz przemian kulturowych wyrazy te zmieniły swoje znaczenia $z$ neutralnych na pejoratywne, by wskutek działalności aktywistów odzyskać swoją pierwotną wymowę, a nawet stać się powodem do dumy. Warto tu wspomnieć o dwóch angielskich słowach, gdyż teoria, która stanowi centrum niniejszych rozważań, narodziła się w anglosaskim kręgu kulturowym: queer i crip. Wspominam o nich nieprzypadkowo, ponieważ obie teorie wyrosły z bardzo podobnego źródła; co więcej, w opracowaniach na temat crip theory często wymie-

${ }^{1} \mathrm{Z}$ pewnością takie określenia występują też $\mathrm{w}$ innych językach świata, $\mathrm{z}$ uwagi jednak na brak kompetencji lingwistycznych z zakresu na przykład orientalistyki, autorka niniejszego artykułu ograniczy się wyłącznie do języków używanych na kontynencie europejskim i/lub w rejonach, które były częściami kolonii brytyjskich, francuskich itd. 
nia się kategorię queer jako pokrewną tej odmianie refleksji nad niepełnosprawnością w kulturze 2 .

Kategoria crip, podobnie jak queer, wyrosła z kontestacji wobec współczesnego rozumienia takich wartości, jak akceptacja, tolerancja czy asymilacja, a także niezgody na neoliberalny paradygmat w kulturze zachodniej (McRuer, 2011, s. 107-117). Robert McRuer zauważa, że podobnie jak w przypadku widocznej heteronormy (przekonania, że heteroseksualność jest jedyną uznaną normą, jako że stanowi doświadczenie większości), w świadomości społecznej także uznaje się pełną sprawność cielesną za oczywistą normę, która jest miarą wszechrzeczy i jako taka ma prawo do widoczności oraz reprezentacji w kulturze (McRuer, 2006, s. 2-3). Crip theory ściśle wiąże się z refleksją nad społeczną konstrukcją ciała, stanowi próbę poszukiwania odpowiedzi na to, w jaki sposób niepełnosprawność jest materializowana w różnych przestrzeniach kultury (McRuer, 2006, s. 33-34). McRuer przywołuje w tym kontekście prace Carrie Sandahl, autorki eseju Queering the Crip or Cripping the Queer? z 2003 roku (Sandahl, 2003, s. 25-26), która nie tylko powiązała kategorię crip z aktywizmem na rzecz mniejszości, ale także zwróciła uwagę na performatywny aspekt niepełnosprawności. Sandahl poszła nawet krok dalej niż większość badaczy zajmujących się studiami nad niepełnosprawnością. Twierdziła bowiem, że disability studies nie są niczym innym jak pewną odmianą queer studies (Sandahl, 2003, s. 26). Jej zdaniem, disability studies zrodziły się ze sprzeciwu wobec „reżimu normalności”, a niepełnosprawność sama w sobie jest czymś więcej niż tylko medyczną kondycją czy formą tożsamości jednostki: stanowi punkt wyjścia refleksji nad historią oraz wyobrażeniami dotyczącymi przyszłości. Zwraca również uwagę na pejoratywny w swym wydźwięku charakter słowa cripple 3 , które jednakże jest płynne i ulega zmianom, podobnie jak queer,

${ }^{2}$ Crip theory $\mathrm{w}$ źródłach anglojęzycznych niekiedy jest rozważana $\mathrm{w}$ kontekście i $\mathrm{w}$ ramach disability studies (zob. Bone, 2017, s. 1297-1314). Krytycy, tacy jak Bone, zwracają jednak uwagę na fakt, że choć badacze posługujący się w swojej refleksji naukowej studiami nad niepełnosprawnością sięgają niekiedy po narzędzia, które proponuje crip theory, to nie daje ona możliwości zbudowania pomostu między akademickimi rozważaniami i realnym życiem osób z niepełnosprawnościami, głównego celu studiów nad niepełnosprawnością, od samego początku związanych $\mathrm{z}$ aktywizmem na rzecz tej grupy społecznej.

3 Ten wyraz można przetłumaczyć na polski jako „kaleka” lub „inwalida”, które w przeszłości w naszym języku nie zawsze miały negatywny wydźwięk (na przykład w okresie dwudziestolecia międzywojennego, o czym świadczą dokumenty z epoki dotyczące poszczególnych ugrupowań lub akcji na rzecz poszkodowanych podczas pierwszej wojny światowej). Wydaje się, że te wyrażenia w języku polskim nabrały pejoratywnego charakteru w okresie PRL-u, zwłaszcza w epoce stalinowskiej, gdy niepełnosprawność stała się tematem nieobecnym w oficjalnej narracji państwowej. Od przełomu lat osiemdziesiątych i dziewięćdziesiątych XX wieku można zaobserwować odchodzenie od ich używania w oficjalnej polszczyźnie, choć nadal występują one w języku potocznym jako określenia nacechowane raczej negatywnie. 
które nie odnosi się już wyłącznie do osób homoseksualnych (Sandahl, 2003, s. 27) $)^{4}$.

Crip oznacza więc ciągłe kontestowanie norm, stałe kwestionowanie cielesnej sprawności jako jedynej możliwej perspektywy oceniania rzeczywistości, przekroczenie dualizmu niepełnosprawny - sprawny. Jest to próba zetknięcia się z „radykalną innością” bez prób jej oswojenia czy zrozumienia (McRuer, 2006, s. 180 -184). McRuer wymienia w tym kontekście przykład uznanej za kontrowersyjną twórczości Boba Flanagana, poety i performera, mężczyzny żyjącego z mukowiscydozą (1952-1996), jako tego, który ujawniał paradoksy ciała oraz możliwość przekroczenia wszelkich dotąd powstałych narracji o niepełnosprawności.

Można w tym miejscu postawić pytania: czy kategoria crip ma swoje odpowiedniki w polskiej kulturze? Jak (jeśli w ogóle) w naszym kraju realizuje się potencjał cripu? W jakich tekstach kultury można odnaleźć kategorię crip?

\section{Crip po polsku}

W uzyskaniu odpowiedzi na sformułowane pytania warto sobie uświadomić, co wpływa na postrzeganie niepełnosprawności oraz na jej społeczny odbiór w kulturze polskiej. Można wyróżnić w tym zakresie cztery czynniki. Pierwszym jest religia chrześcijańska, szczególnie rzymski katolicyzm (protestantyzm, z ewangelicko-augsburską reprezentacją w większości, miał i ma nadal niewielki wpływ na konstruowanie obrazu niepełnosprawności w Polsce; co więcej, jest on ograniczony terytorialnie do Śląska Cieszyńskiego i niektórych aglomeracji, podobnie jak judaizm przed II wojną światową). W odniesieniu do drugiej połowy XX wieku warto zwrócić uwagę szczególnie na wpływ pontyfikatu Jana Pawła II, który w wielu swoich wystąpieniach podejmował temat niepełnosprawności i choroby. Drugim jest ideologia romantyczna, która kładzie akcent na mesjański charakter polskiej kultury, ale także na przywrócenie głosu wszelkim marginalizowanym grupom, w tym na przykład chorym psychicznie lub niepełnosprawnym dzieciom (Janion, 1975; Janion, 2000). Trzeci czynnik to dziedzictwo przedchrześcijańskiej Słowiańszczyzny wraz z jej pozostałościami w kulturze ludowej, co w szczególności przejawia się w określonych praktykach kulturowych związanych z niepełnosprawnością na polskiej wsi. Czwartym jest kultura popularna, wywierająca coraz większy wpływ na młode pokolenia Polaków, choć nieograniczająca się wyłącznie do nich (Oslund, 2015) 5 .

${ }^{4}$ W takim ujęciu kategoria queer może obejmować wszystkich, którzy w jakimś stopniu odbiegają od ogólnie przyjętej normy, w zależności od kontekstu mogą być to również na przykład ludzie o bardzo konserwatywnym światopoglądzie.

${ }^{5}$ Badania wykonane przez autorkę w ramach projektu „Recepcja tematu niepełnosprawności wśród uczniów polskich szkół podstawowych” (finansowanego przez PFRON) wykazały, że dzieci 
Wydaje się, że wobec takich czynników kultura polska ma wielki potencjał do wypracowania lokalnej odmiany cripu. Co więcej, okazuje się, że cripowa perspektywa pojawia się na rodzimym gruncie tam, gdzie jest najmniej spodziewana: w literaturze dziecięcej. W jaki sposób? Aby zyskać odpowiedź na to pytanie, warto przyjrzeć się dwóm różnym dziełom literackim: wierszowi ks. Jana Twardowskiego Do moich uczniów oraz powieści Doroty Terakowskiej Poczwarka.

\section{Oddanie innego głosu}

Oba utwory powstały w odmiennych kontekstach społecznych i politycznych, także ich autorzy reprezentowali różne światopoglądy i doświadczenia w życiu prywatnym. Do moich uczniów ukazał się po raz pierwszy w tomiku Powrót Andersena z 1959 roku (Twardowski, 1996), będąc jednocześnie poetyckim zapisem uczuć i wspomnień z rzeczywistej pracy Jana Twardowskiego w szkole dla dzieci z różnymi niepełnosprawnościami na początku lat pięćdziesiątych XX wieku (Grzebałkowska, 2011). Co więcej, ten utwór można traktować jako swoiste przełamanie literackiego tabu, jakim stała się w okresie stalinowskim niepełnosprawność nie tylko w twórczości dla dzieci i młodzieży, ale w przestrzeni publicznej w ogóle ${ }^{6}$. Co interesujące, niepełnosprawność zanikła jako przedmiot dyskursu publicznego w Polsce na całą dekadę. Prawdopodobnie spowodowało to taki, a nie inny rozwój debaty na ten temat w naszym kraju, na wiele lat ograniczając go wyłącznie do kwestii zdrowotnych i ekonomicznych, a także przyczyniło się do utrwalenia postaw ableistycznych w społeczeństwie. Dlatego wiersz Jana Twardowskiego można uznać za swoisty przełom; co więcej, w kontekście zachodzących w połowie XX wieku przemian wewnątrz eklezjologii i soterologii katolickiej stanowił on istotny głos w obronie osób z niepełnosprawnościami (Kiciński, 2010, s. 213-220).

W przypadku Poczwarki Doroty Terakowskiej również można mówić o przełomowym charakterze dzieła, wydanym (co również wydaje się znamienne) w 2001 roku. O ile jednak poezja Twardowskiego stanowiła powrót niepełno-

i młodzież w wieku od dziewięciu do szesnastu lat znają liczne teksty kultury, które poruszają tematykę związaną z niepełnosprawnością. Są to zarówno seriale telewizyjne, jak i literatura dziecięca oraz gry komputerowe.

${ }^{6}$ W latach 1949-1956 niepełnosprawność pojawiała się właściwie wyłącznie w propagandowych narracjach literackich lub filmowych, których celem było porównanie losu tych ludzi przed wojną i po wojnie (z podkreśleniem pozytywnych zmian po 1945 roku i przedstawianiem okresu przedwojennego wyłącznie w negatywnym świetle), lub opisy niepełnosprawności jako zjawiska społecznie niepożądanego, kojarzonego z patologią społeczną, np. alkoholizmem. Taki sposób reprezentacji niepełnosprawności w przestrzeni publicznej przetrwał do 1959 roku, kiedy powstały pierwsze po okresie stalinowskim reprezentacje literackie, ale wyraźniejsze zmiany można zauważyć dopiero w latach sześćdziesiątych XX wieku. 
sprawności jako tematu w polskiej literaturze dziecięcej po okresie stalinowskim, o tyle Poczwarka otwiera zupełnie nowy sposób pisania o tym zjawisku, opis, którego różne warianty występują do dziś. Choć według samej Terakowskiej powieść ta była pierwotnie skierowana do osób dorosłych jako reakcja na własne obserwacje niepełnosprawnego dziecka z sąsiedztwa, warto odnotować fakt, że na początku XXI wieku zyskała popularność wśród dziecięcych i nastoletnich czytelników ${ }^{7}$. Co więcej, tuż przed ukazaniem się pierwszego wydania powieści Terakowskiej tematykę związaną z niepełnosprawnością w kulturze szeroko podejmowały już media głównego nurtu. Lata dziewięćdziesiąte ubiegłego wieku to czas kształtowania się nowoczesnych grup wsparcia oraz polskiego ruchu na rzecz równych praw osób z niepełnosprawnościami. Rozwijało się wtedy szkolnictwo integracyjne, a encykliki papieskie dotyczące miłosierdzia wobec tej grupy społecznej były szeroko komentowane w różnych kontekstach i chętnie słuchane w wielu domach. Serial telewizyjny Klan, w którym pojawiła się postać Maćka, chłopca z zespołem Downa, szybko stał się jedną z najczęściej oglądanych produkcji TVP.

Jednocześnie można zaryzykować stwierdzenie, że oba teksty literackie dają się interpretować jako swoisty protest przeciwko powierzchownemu podejściu do fenomenu niepełnosprawności, zarówno w czasach PRL-u, jak i współcześnie. Co jednak istotniejsze z perspektywy teorii crip, zarówno w wierszu Twardowskiego, jak i w powieści Terakowskiej można zauważyć negację pełnosprawnej perspektywy, a przynajmniej zaprezentowanie niepełnosprawnej alternatywy w postrzeganiu rzeczywistości. Warto zwrócić uwagę szczególnie na fakt, że choć ci autorzy reprezentowali różne światopoglądy ${ }^{8}$, w obu przypadkach za przestrzeń umożliwiającą stworzenie takiej alternatywy oraz zanegowania pełnosprawnej matrycy jako jedynie pewnej i normalnej uznali szeroko pojętą duchowość, jeśli przyjąć w tym kontekście definicję duchowości jako swoistą relację z Wyższą Mocą (Jarosz, 2010), którą w zależności od przyjętego systemu można nazywać Bogiem, naturą lub Absolutem. Wydaje się jasne, że to właśnie ten fenomen w przypadku kultury polskiej umożliwia pojawienie się cripu.

Jednocześnie warto zwrócić uwagę na to, że cripowe w swym charakterze postacie Twardowskiego i Terakowskiej stoją niejako w opozycji do religijności rozumianej jako zorganizowany system tradycji oraz wierzeń, co było charakterystyczne dla tego ujęcia tematu w drugiej połowie XX wieku (Jarosz, 2010, s. 12-13). W związku z tym Do moich uczniów oraz Poczwarka wpisują się w nurty filozoficzne, teologiczne i stan wiedzy naukowej swoich czasów.

7 Świadczą o tym liczne strony internetowe zawierające recenzje, streszczenia powieści na użytek szkolny, ale także doświadczenia samej autorki artykułu oraz jej rówieśników z lat 20032005.

${ }^{8}$ Jan Twardowski jako kapłan rzymskokatolicki, Dorota Terakowska natomiast jako osoba nastawiona sceptycznie wobec zorganizowanej religii, sytuując się blizzej duchowości synkretycznej lub bliskiej ideom New Age (Beszczyńska, 2000). 
Negacja pełnosprawnej normy dokonuje się w obu przypadkach już w sferze opisu pewnej grupy:

Janko Kosiarska z rączkami sztywnymi, z nosem, co się tak uparł, że pozostał krótki za oknem wiatr czerwcowy z pannami ładnymi a tobie kto daruje choć uśmiech malutki.

Pamiętasz tamtą lekcję, gdym o niebie mówił, te łzy, co w okularach na religii stają właśnie o robotnikach myślałem z winnicy, co wołali na dworze: Nikt nas nie chciał nająć.

Twardowski, 1996, s. 29-30

Dziecko z niepełnosprawnością staje się w tej sytuacji egzemplifikacją ewangelicznego prostaczka, który należy do grupy obdarowanej szczególnym błogosławieństwem Chrystusa. Można zaryzykować stwierdzenie, że eschatologiczny wymiar Chrystusowej przypowieści nabiera w kontekście dziecięcej niepełnosprawności innego charakteru. Praca w winnicy, interpretowana jako szeroko rozumiana służba Bogu w królestwie niebieskim, zostaje dla niepełnosprawnych dzieci zamknięta, ponieważ „nikt ich nie chciał nająć”. Jednocześnie one same nie zostają zupełnie wykluczone z przestrzeni sacrum. Przeciwnie, jest z nimi „ten od głupich dzieci”, jak określa samego siebie autor wiersza, stojąc po stronie wykluczonych ze świata oficjalnej dogmatyki. Crip przejawia się w tym wierszu w zakwestionowaniu takich form życia religijnego, które za jedyną normę uznają doświadczenia duchowe ludzi w pełni sprawnych.

W przypadku Poczwarki ta cripowa perspektywa jest jeszcze mocniej zarysowana, zarówno w naturalistycznych opisach cielesności Marysi, dziewczynki z zespołem Downa, jak i w reprezentacji świata jej wyobraźni, wypełnionego motywami z Księgi Rodzaju (ma to oczywisty związek z faktem, że matka dziecięcej bohaterki czytała jej fragmenty z tej części Biblii), a zwłaszcza opisem stworzenia (Lisowski, 2001). Podobnie jak w wierszu Twardowskiego, można zaobserwować tu wyraźne zanegowanie pełnosprawnej perspektywy religijnej:

Stwarzając, Pan zawsze rozglądał się za swymi Darami, za dziećmi rozrzuconymi po różnych światach, i przywoływał niektóre z nich z powrotem, by dać im lekkość motyla i umiejętność tańca. Pan wiedział, że taniec to radość życia, radość świata, radość z własnego ciała - i obdarzył je tęsknotą za nim. Tęsknotą za tym, co niemożliwe. Po to, by zarażały nią ludzi.

Terakowska, 2001, s. 55

Terakowska, posługując się językiem mitu, stwarza (nomen omen) odmienną wizję Boga równie cripowego, jak Marysia: Stwórca jawi się w tym ujęciu jako 
istota zdecydowanie odmienna od tego, co można poznać w codzienności (zupełnie jak dziewczynka z poważną formą zespołu Downa). Jednocześnie można tu zauważyć koncepcję „słabego Boga”, który pozostaje w pełni zależny od wyobraźni dziewczynki.

\section{Cripowy aspekt kultury polskiej — próba podsumowania}

Wbrew obiegowej opinii nowe zjawiska kulturowe lub próby ich opisu wcale nie muszą funkcjonować poza oficjalnymi narracjami, nie muszą też wzbudzać w oczywisty sposób kontrowersji (jak na przykład happeningi, poezja i performance Boba Flanagana w Stanach Zjednoczonych). W Polsce, która przez wiele lat stanowiła terytorium zależne względem imperiów, można zauważyć takie przekształcenia dyskursu publicznego, które umożliwiły powstanie nowej jakości i przekaz treści nieczytelnych dla środowiska zewnętrznego (Bachórz, Kowalczykowa, 1991, s. 249-250). Niekiedy nowa narracja pojawia się w tekstach, które przez krytyków i media niekoniecznie są uznawane za dość „poważne” lub „klasyczne". Wydaje się, że taki przypadek zakwestionowania oficjalnej, pełnosprawnej narracji dokonał się już w polskiej kulturze, ze względu jednak na lokalną specyfikę nie został do tej pory zauważony ${ }^{10}$.

Crip w polskiej przestrzeni jest już dobrze ulokowany, choć brakuje na jego temat bardziej rozbudowanych opracowań, wykraczających poza analizę jednostkowych dzieł lub incydentalnych wzmianek na jego temat. Zakwestionowanie pełnosprawnej normy dokonało się wskutek użycia języka religii $\mathrm{w}$ takich dziełach, które większość odbiorców uznaje za nieprzystające do rozpoczęcia oficjalnej dyskusji na temat miejsca osób z niepełnosprawnościami w społeczeństwie, i to mimo ogólnie pozytywnej recepcji twórczości Jana Twardowskiego oraz Doroty Terakowskiej.

\section{Literatura}

Bachórz J., Kowalczykowa A., 1991, Stownik literatury polskiej XIX wieku, WarszawaWrocław.

9 Przykładem tego może być literatura dla dzieci XIX wieku, w której możliwe było umieszczenie treści patriotycznych ze względu na obniżoną czujność cenzorów. Zob. Kuliczkowska, 1975.

${ }^{10} \mathrm{~W}$ przypadku literatury dla dorosłych taki rodzaj narracji pojawił się w powieści Beza autorstwa Kingi Konińskiej. Książka ukazała się nakładem Wydawnictwa Książkowego „Linia” w 2019 roku. Niestety, z uwagi na trwającą od przełomu 2019 i 2020 roku pandemię COVID-19, nie doszło w przestrzeni medialnej do szerszej dyskusji ani na temat samego dzieła, ani praw osób z niepełnosprawnościami, choć w mediach społecznościowych widać było spore zainteresowanie książką. 
Beszczyńska Z., 2000, Wszystko odwrócić, „Nowe Książki” nr 3. http://terakowska.art.pl/ wywiady/talk3.htm [data dostępu: 19.04.2020].

Bone K.M., 2017, Trapped Behind the Glass: Crip Theory and Disability Identity, „Disability \& Society", vol. 32, no. 9.

Grzebałkowska M., 2011, Ksiądz Paradoks. Biografia Jana Twardowskiego, Kraków. Janion M., 1975, Goraczka romantyczna, Warszawa.

Janion M., 2000, Do Europy tak, ale razem z naszymi umartymi, Warszawa.

Jarosz M., 2010, Pojęcie duchowości w psychologii, w: Gorbaniuk O., Kostrubiec-Wojtachnio B., Musiał D., Wiechetek M., „Studia z Psychologii w Katolickim Uniwersytecie Lubelskim", t. 16, s. 9-11.

Katecheza ewangelizacyjna. Poszukiwania koncepcji, Mąkosa P., red., Lublin 2010.

Kosińska K., 2019, Beza, Warszawa.

Kiciński A., Ewangelizacja środowisk życia osób niepełnosprawnych, w: Mąkosa P., red., Katecheza ewangelizacyjna. Poszukiwania koncepcji, Lublin 2010, s. 213-220.

Kuliczkowska K., 1975, Literatura dla dzieci i młodzieży w latach 1864-1918, Warszawa.

McRuer R., 2006, Crip Theory: Cultural Signs of Queerness and Disability, New York.

McRuer R., 2011, Disabling Sex: Notes for a Crip Theory of Sexuality, „GLQ: A Journal of Lesbian and Gay Studies", no. 17, s. 107-117.

Oslund C., 2015, Disability Services and Disability Studies in Higher Education: History, Contexts, and Social Impacts, New York.

Sandahl C., 2003, Queering the Crip or Cripping the Queer?, „GLQ: A Journal of Lesbian and Gay Studies", vol. 9, no. 1-2. https://www.ces.uc.pt/projectos/intimidade/me dia/Queering\%20the\%20crip_sandahl.pdf [data dostępu: 10.03.2020].

Stwarzanie świata. Krzysztof Lisowski, poeta, rozmawia z Dorotą Terakowską 2001, „Gazeta Wyborcza” z 8.03.2001. http://galaxy.uci.agh.edu.pl/ joanna/terdor/poczw/ wywiad1.htm [data dostępu: 17.04.2020].

Terakowska D., 2001, Poczwarka, Kraków.

Twardowski J., 1996, Wiersze, Białystok.

Alicja Fidowicz - doktor nauk humanistycznych, pracuje na Wydziale Polonistyki Uniwersytetu Jagiellońskiego w Krakowie. Jest autorką monografii Wiejskie dzieciństwo. Branko Ćopić i Tadeusz Nowak (2018). W 2019 roku obroniła pracę doktorską Niepetnosprawni bohaterowie polskiej literatury dla dzieci i młodzieży XX i XXI wieku. Do jej zainteresowań naukowych zaliczają się studia nad niepełnosprawnością, literatura dla dzieci i młodzieży w kontekście komparatystycznym oraz kontakty polsko-słoweńskie i polsko-chorwackie.

e-mail: alicja.fidowicz@uj.edu.pl 